\section{artelogie}

\section{Artelogie}

Recherche sur les arts, le patrimoine et la littérature de I'Amérique latine

\section{$11 \mid 2017$}

Délocalités, translocalités et activisme dans l'art électronique et biomédiale latino-américain

\title{
Video 1- Inner Telescope (2007-2017).
}

Pat Badani interveiws Eduardo Kac (1)

\section{Pat Badani and Eduardo Kac}

\section{(2) OpenEdition \\ Journals}

Electronic version

URL: http://journals.openedition.org/artelogie/1657

DOI: 10.4000/artelogie. 1657

ISSN: 2115-6395

\section{Publisher}

Association ESCAL

Electronic reference

Pat Badani and Eduardo Kac, « Video 1- Inner Telescope (2007-2017). », Artelogie [Online], 11 | 2017,

Online since, connection on 15 September 2020. URL : http://journals.openedition.org/artelogie/1657

This text was automatically generated on 15 September 2020 .

Association ESCAL 


\section{Video 1- Inner Telescope (2007-2017).}

Pat Badani interveiws Eduardo Kac (1)

\section{Pat Badani and Eduardo Kac}

This media file cannot be displayed. Please refer to the online document http:// journals.openedition.org/artelogie/1657 